Pratama Widya : Jurnal Pendidikan Anak Usia Dini

Volume 6, No. 1, April 2021

pISSN: 25284037 eISSN: 26158396

https://www.ejournal.ihdn.ac.id/index.php/PW/issue/archive

\title{
STRATEGI ORANG TUA DALAM MENDAMPINGI ANAK USIA DINI BELAJAR DARING DI RUMAH
}

\author{
Oleh : \\ Ida Bagus Alit Arta Wiguna ${ }^{1}$, Ni Luh Drajati Ekaningtyas ${ }^{2}$ \\ ${ }^{1,2}$ Institut Agama Hindu Negeri Gde Pudja Mataram \\ e-mail: gusarta.iahn@gmail.com,drajatieka@gmail.com
}

Diterima 2 Maret 2021, direvisi 31 Maret 2021, diterbitkan 1 April 2021

\begin{abstract}
Abstrak
Pendidikan anak usia dini merupakan tanggung jawab bersama berbagai pihak, bukan hanya pemerintah, tetapi juga sekolah, guru dan keluarga (orang tua). Penelitian ini bertujuan untuk mengetahui strategi yang digunakan orang tua dalam mendampingi anak selama belajar daring di rumah. Penelitian ini menggunakan teknik eksplorasi deskriptif dengan analisis kualitatif. Pengumpulan data dilakukan pada tiga PAUD yang berbeda. Hasil analisis data menunjukkan bahwa TK.A melaksanakan pembelajaran daring secara utuh dan menggunakan strategi pendampingan oleh orang tua yakni mempersiapkan perlengkapan belajar, memantau anak saat pembelajaran, membantu anak dalam menerangkan materi yang tidak dimengerti. PAUD B menerapkan pembelajaran semi daring dengan strategi orang tua mengambil dan mengumpulkan pekerjaan rumah anak setiap hari Senin. Sedangkan PAUD C menerapkan pembelajaran luring dengan strategi pendampingan yakni guru melaksanakan kunjungan kerumah siswa. Orang tua di PAUD $\mathrm{C}$ hanya berperan sebagai pengawas anak dalam melaksanakan pembelajaran, dimana orang tua pulang dari bekerja dan meluangkan waktu untuk mendampingi anaknya, kemudian orang tua menyarankan kepada gurunya untuk berkunjung kerumah. Secara umum dapat disimpulkan bahwa pada dasarnya orang tua tidak memiliki alasan untuk tidak memberikan pendampingan kepada anak saat belajar dari rumah dimasa pandemi Covid-19. Sinergisitas antara guru dan orang tua dalam pendidikan anak usia dini menjadi esensi dari terlaksanakannya pembelajaran dengan baik.
\end{abstract}

Kata Kunci: Peran Orang Tua, BDR, WFH, Belajar Daring, Covid-19

\begin{abstract}
Early childhood education is a shared responsibility of various parties; not only the government, but also schools, teachers and families (parents). During online learning, learning activities at home are part of the responsibiliy of the parents. This study aims to determine the strategies used by parents in accompanying their children during online learning at home. This research uses descriptive exploration techniques with qualitative analysis. Data collection was carried out in three different early childhood education institutions (PAUD). The results of the data analysis shows that TK A carries out full online learning and uses mentoring strategies by parents including preparing learning equipments, monitoring children during learning, and explaining subjects that are not understood by the children. PAUD B applies semi-online learning using a strategy: parents take and collect children's homework every Monday. Meanwhile, PAUD C implements offline learning with a mentoring strategy in which the teacher conducts home visits. Parents in PAUD C have a role to supervise their children in learning, where parents come home from work and take the time to accompany their children, then advise the teachers to visit their homes. In general, it can be concluded that basically parents have no reason to not provide assistance to their children while learning from home during the COVID-19 pandemic. The synergyy between teachers and parents is the essence of a good early childhood education.
\end{abstract}

Keywords: Work From Home, Parental Assistance, Learning From Home, Blanded Learning, Corona Virus Disease 2019 


\section{Pendahuluan}

COVID-19 telah melanda sebagian

besar negara dan wilayah di dunia. Berdasarkan statistik Organisasi Kesehatan Dunia (WHO), pada 25 Februari 2021, 211 negara dan wilayah telah melaporkan kasus yang dikonfirmasi, dan kumulatif jumlah kasus yang dikonfirmasi telah mencapai lebih 112 juta (World Health Organization, 2021). Terpengaruh oleh pandemi Covid-19 seluruh aktivitas siswa di seluruh dunia tidak dapat melaksanakan pembelajaran di sekolah secara normal. Menurut pemantauan Organisasi Pendidikan, Ilmu Pengetahuan, dan Kebudayaan Perserikatan Bangsa-Bangsa (UNESCO), pada bulan desember, 211 negara telah menerapkan pembelajaran dari rumah secara nasional, yang memengaruhi sekitar 1.575 Miliar siswa yang merupakan $91,3 \%$ dari total jumlah siswa yang terdaftar di seluruh dunia (UNESCO, 2020).

Karena itu, negara-negara mulai mencari cara yang efktif untuk meminimalisir dampak pandemi pada bidang pendidikan. Pembelajaran online atau dalam jaringan (Daring) telah menjadi solusi bagi banyak negara untuk belajar selama pandemi baik dari PAUD, SD, SMP, SMA dan perguruan tinggi di dunia menerapkan Pembelajaran online untuk meminimalisir terinfeksi virus Covid-19 (Gunada, 2020). Sejalan dengan peringatan dari UNESCO di Indonesia pemerintah indonesia juga menerapkan Pembelajaran jarak jauh sesuai dengan SE Mendikbud Nomor 4 Tahun 2020. Tentang pelaksanaan Kebijakan Pendidikan dalam Masa Darurat Penyebaran Covid-19, menyatakan bahwa proses belajar dilaksanakan di rumah melalui pembelajaran daring/pembelajaran jarak jauh untuk memberikan pengalaman belajar yang bermakna bagi siswa dengan mempertimbangkan kesenjangan akses/fasilitas belajar di rumah serta tidak lagi memberi penilaian secara kuantitatif namun nilai diberi secara kualitatif sesuai dengan perkembangan peserta didik. (Kemdikbud, 2020)

Untuk mendukung pembelajaran dari rumah Pemerintah memberikan pedoman terkait pembelajaran daring melalui SE Sesjen Mendikbud Nomor 15 Tahun 2020. Tentang pedoman penyelenggaraan belajar dari rumah dalam masa darurat penyebaran corona virus disease (covid-19) Pelaksanaan Belajar Dari Rumah selanjutnya disebud (BDR) oleh orang tua atau wali peserta didik pendampingan Pembelajaran Jarak Jauh ada yang daring, ada yang semi daring, dan ada yang luring. Dua pendekatan yaitu pembelajaran jarak jauh dalam jaringan (daring) dan luar jaringan (luring) orang tua atau wali terhadap peserta didik menyesuaikan kondisi, dan ketersediaan waktu dan sarana dan prasarana pembelajaran. Waktu pembelajaran sesuai kesepakatan orang tua atau wali dengan guru dan peserta didik. (Kemdikbud, 2020) Pendidikan adalah sebuah tanggung jawab bersama bukan hanya pemerintah, tetapi juga sekolah (guru), dan keluarga (orang tua) (Hatimah, 2016). Kegiatan proses belajar mengajar dilaksanakan di rumah dan menjadi tanggungjawab orang tua. Kesiapan belajar dari rumah ini dapat dilihat dari bagaimana orang tua dalam membimbing anak selama belajar di rumah. Tidak semua orang tua siap menjalankan pekerjaan rumah sekaligus menjadi peran guru pengganti selama BDR. Sebagai contoh guru memberikan tugas melalui grup WhatsApp atau melalui aplikasi Google Classroom atau melalui platform Google Meet, Zoom Meeting, dan sebagainya untuk mengintegrasikan teknologi dalam proses belajar mengajar virtual (Okmawati, 2020).

Tugas diberikan oleh guru secara bertahap sesuai dengan jadwal mata pelajaran pada hari tertentu. Peserta didik kemudian mengerjakan tugas secara mandiri dirumah. Namun pemberian tugas ini tidak mementingkan nilai secara kuantitatif namun justru lebih melihat 
keseriuasan anak untuk melaksanakan pembelajaran. Guru juga wajib memantau melalui platform yang telah disetujui oleh orang tua agar anak benar-benar melaksanakan proses pembelajaranya. Guru berkoordinasi aktif dengan orang tua melalui gawai pintar baik secara pesan WhatsApp atau penggunaan platform yang lainnya (Purwanto \& Adriyani, 2020). Dengan adanya pembelajaran daring menambah tugas orang tua sekaligus menjadi peran guru di rumah. Orang tua harus terlibat dalam proses belajar mengajar anak sebagai mentoring sekaligus fasilitator. Dengan terlibatnya orang tua mendampingi anak menjadi alternatif yang dapat digunakan untuk meningkatkan kemampuan anak.

Peran orang tua menjadi sangat penting ketika anak mulai bersekolah di rumah. Karena orang tua atau keluarga pada dasarnya adalah tempat pendidikan yang pertama bagi anak. hal tersebut sesuai dengan pendapat dari Mutiah, yang menyatakan bahwa mengasuh, membina, dan mendidik anak di rumah merupakan kewajiban bagi setiap orang tua dalam usaha membentuk pribadi anak (Mutiah, 2016). Orang tua bertugas mendampingi anak dalam mempersiapkan media yang akan digunakan anak (Ardika Yasa, 2020), mendampingi proses belajarnya dan masih banyak lagi peran orang tua yang dapat memaksimalkan proses belajar mengajar di rumah melalui daring. Pendampingan orang tua dalam pembelajaran dari rumah selain membantu anak dalam momen belajar juga akan membangun komunikasi yang intens dengan anak. Komunikasi yang intens ini akan membangun kreativitas anak lewat berbagai aktivitas bersama yang bermanfaat (Deswari, 2015). Peran guru dan orang tua memang mendasar dalam mendukung proses anak belajar di rumah. Keduanya harus membangun kolaborasi demi memaksimalkan kegiatan belajar anak (Iftitah \& Anawaty, 2020).

Selain guru dituntut untuk kreatif dalam peyampaian materi dan lembar kerja kepada orangtua siswa agar memudahkan orang tua untuk memahami secara teori terkait materi yang ingin disampaikan oleh guru, tidak kalah penting dalam BDR orang tua harus memiliki kemampuan dan strategi dalam menguasai materi secara ringkas dan padat. Namun kenyataan dilapangan sangat berbeda banyak orang tua siswa dari latar belakang yang berbedabeda baik secara umur, materiil dan kemampuan dalam penguasaan teknik pembelajaran untuk mendampingi anak usia dini belajar dirumah agar tidak membosankan. Penelitian ini membahas fokus membahas strategi orang tua dalam mendampingi anak usia dini belajar daring di rumah.

\section{METODE}

Penelitian ini dilakukan pada orang tua / wali siswa di tiga sekolah PAUD yang berbeda dan pada berbagai tingkatan di kota Mataram dan Kab. Lombok Barat Provinsi Nusa Tenggara Barat. Penelitian yang digunakan dalam penelitian ini adalah eksplorasi deskriptif dengan analisis kualitatif, peneliti adalah bagian integral dari data, artinya peneliti ikut aktif dalam menentukan jenis data yang diinginkan (Lexy J. Moleong, 2019). Dengan demikian, periset menjadi instrument riset yang harus terjun langsung di lapangan. Karena itu riset ini bersifat subjektif dan hasilnya lebih kasuistik bukan untuk digeneralisasikan. Desain riset dapat dibuat bersamaan atau sesudah riset. Desain dapat berubah atau disesuaikan dengan perkembangan riset.

Untuk mengetahui bagaimana strategi orang tua dalam mendampingi anak usia dini belajar daring di rumah, peneliti memberikan kuesioner kepada orang tua/wali siswa yang dilakukan menggunakan Google Form dan selanjutnya dilakukan wawancara terhadap responden yang dipilih secara acak. Penelitian ini dilaksanakan di (1) TK PGRI 1 Mataram yang berlokasi di daerah pemukiman yang notabene perumahan dan perkotaan. Mengambil di kelas B1 yang 
memiliki jumlah 24 siswa selanjutnya akan disebut (TK A), (2) PAUD Mentari yang berlokasi diperbatasan Kota Mataram dan Kabupaten Lombok Barat berjumlah 25 siswa selanjutnya akan disebut (PAUD B). (3) PAUD Kumara Cita yang berlokasi daerah 3T memiliki 17 siswa selanjutnya akan disebut (PAUD C). fokus penelitian ini adalah strategi orang tua mendampingi anak usia dini belajar daring di rumah.

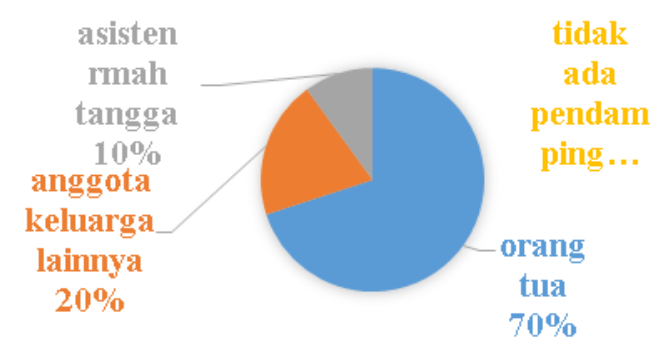

Gambar 1. Persentase orang yang mendampingi siswa belajar dari rumah

Terlihat pada gambar diatas bahwa dominan orang tua sebanyak $70 \%$ dalam mendampingi anak belajar dirumah dan $20 \%$ dari keluarga lainnya seperti kakek/nenek, kakak, sepupu atau paman. Sedangkan $10 \%$ didampingi oleh asisten rumah tangga.

\section{PEMBAHASAN}

Penyebaran pandemi Covid-19 secara global menjadi tantangan besar bagi semua negara di dunia dalam berbagai sektor kehidupan, termasuk bidang pendidikan. Pemerintah melalui Kementerian Pendidikan dan Kebudayaan telah mengeluarkan berbagai kebijakan untuk mencegah penyebaran virus tersebut, termasuk kebijakan pengajaran online dan penghapusan ujian akhir nasional. Melalui Surat Edaran Nomor 3 Tahun 2020 tentang Pencegahan Covid-19 di Satuan Pendidikan, Menteri Pendidikan dan Kebudayaan Nadiem Makarim menginstruksikan seluruh Satuan Pendidikan di semua jenjang mengenai petunjuk teknis pencegahan penyebaran Covid-19 di Indonesia. Ada Tiga juknis disusun menurut kategori risiko yaitu rendah, sedang dan tinggi. Surat Edaran ini mulai berlaku satu minggu sejak pengumuman kasus positif pertama Covid19 di Indonesia yakni sejak 9 Maret 2020. Saat itu, seluruh satuan pendidikan berasal PAUD hingga perguruan tinggi segera pindah ke proses pembelajaran tidak tatap muka atau pengajaran Daring (Rulandari, 2020).

Peneliti harus mengetahui kemampuan orang tua dalam memberikan fasilitas pembelajaran daring terlebih dahulu sebelum melanjutkan penelitian lebih jauh dengan menyebarkan angket via google form serta mewawancarai kepala sekolah PAUD.

Bisa Menggunakan Smartphone

Tidak Bisa menggunakan Smartphone

tidak memiliki smartphone

memiliki smartphone

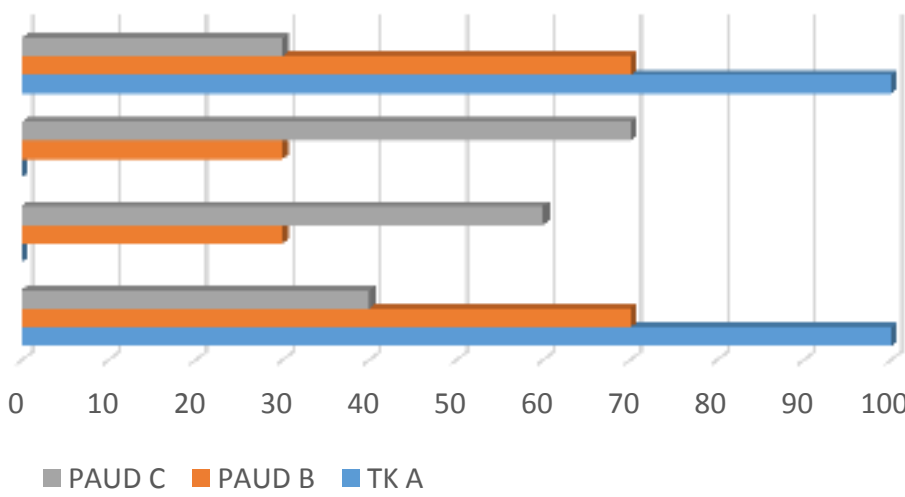

Gambar 2. Persentase kemampuan orangtua dalam memfasilitasi anak belajar daring.

Berdasarkan data diatas sejalan dengan arahan SE Kemdikbud seluruh sekolah mengadakan pertemuan dengan orang tua / wali siswa terlebih dahulu 
untuk menyepakati teknik atau cara yang akan digunakan oleh guru dan orangtua siswa pada pembelajaran daring saat pandemi Covid-19. Dari musyawarah antara guru dan orang tua / wali menghasilkan di TK.A melaksanakan full daring menggunakan aplikasi platform ZOOM Meeting, Google Classroom, WhatsApp. Sedangkan PAUD B menghasilkan musyawarah melaksanakan pembelajaran semi daring dengan cara setiap hari senin orang tua mengambil lembar kerja siswa ke sekolah dan PAUD C menghasilkan musyawarah dilaksanakannya pembelajaran Luring atau di luar jaringan (face - to - face).

Fokus kajian penelitian ini adalah bagaimana strategi orang tua mendampingi anak usia dini belajar daring di rumah dibagi menjadi dua katagori. Yang pertama berdasarkan orang tuanya yang bekerja demi memenuhi kebutuhan sehari-hari dan yang kedua orang tua / wali yang memiliki waktu penuh dirumah menemani anak saat pembelajaran daring dimulai.

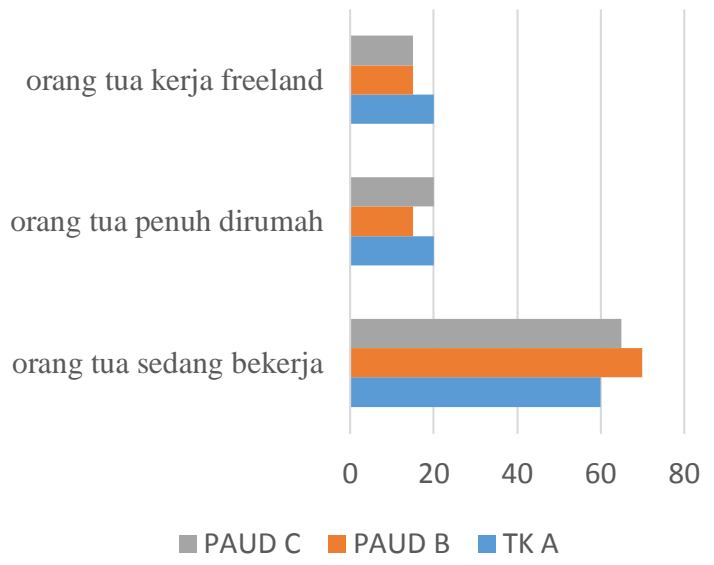

Gambar 3. Persentase status pekerjaan orang tua

Data diatas digunakan untuk menentukan strategi orang tua dalam menemani anak belajar daring dirumah. Berdasarkan persentase diatas lebih dari $60 \%$ orang tua bekerja dengan penuh waktu dan $20 \%$ orang tua bekerja dengan waktu bebas dalam artian apabila ada pekerjaan oran tuanya bekerja dan jika tidak ada kerjaan maka orang tuanya berada dirumah untuk menemani anak belajar daring sedangkan $20 \%$ orang tua tidak bekerja dikarenakan faktor umur serta baru diberhentikan akibat pandemi Covid-19.

Pada awal penerapan kebijakan pembelajaran daring terjadi berbagai macam masalah teknis ditemui dilapangan misalnya: (1) Orang tua anak usia dini yang sedang bekerja untuk memenuhi kebutuhan sehari-hari keluarga, (2) Adapula orang tua yang menjadi IRT namun kurang dalam membaca, menulis dan berhitung sehingga belum mengerti bagaimana caranya menemani anak saat pembelajaran online (3) Orang tua yang belum memiliki fasilitas yang memadai untuk mengikuti kegiatan pembelajaran online seperti tidak memiliki gawai pintar (Smartphone) yang berbasis android atau IOS sehingga ada beberapa siswa PAUD yang harus diberikan pembelajaran khusus.

3.1 Pendampingan belajar AUD oleh Orang Tua yang ada di rumah saat pembelajaran daring

Pembelajaran daring selama pandem Covid-19 memang diharuskan untuk belajar dari rumah (BDR). Biasanya di sekolah PAUD Anak-anak memperoleh pengajaran dari guru yang memiliki kompetensi di bidangnya, akan tetapi selama pandemi dibutuhkan pendampingan orang tua agar belajar mengajar menjadi lebih terarah sesuai yang diharapkan. Meskipun prosesnya berlangsung di rumah, guru akan tetap melakukan evaluasi pada perkembangan anak. Penilaian hasil kegiatan belajar anak dilakukan berdasarkan hasil pengamatan perilaku dan karya yang dibuat anak selama di rumah melalui orang tuanya. Berbagai kegiatan anak di rumah, termasuk semua yang dilakukan oleh anak atau yang dikatakan oleh anak selama belajar dari rumah. berikut 
"..anak saya sekarang berumur tujuh tahun, anak saya belum begitu paham tentang materi pembelajaran yang diberikan oleh gurunya, sehingga membuat saya selalu menanyakan kepada gurunya melalui pesan WhatsApp terkait maksud tugas yang diberikan."

Orang tua dan anak menjadi lebih aktif dalam berkomunikasi dengan adanya pendampingan dan anak menjadi lebih percaya diri karena apa yang belum ia mengerti bisa langsung ditanyakan. Dalam pembelajaran di TK A orang tua perlu menyiapkan smartphone karena pembelajaran dilaksanakan secara daring melalui aplikasi Zoom meeting sesuai dengan jam pelajaran namun hanya lima puluh menit. Guru mengajari anak berbagai materi misalnya menyanyikan lagu-lagu nasional, anggota tubuh serta doa sehari-hari. Beda dengan PAUD B cara pemberian materinya ialah dengan menggunakan pesan Group WhatsApp gurumerekam suaranya melalui perekaman suara lalu dibagikan, anak diharapkan mengikuti arahan dari yang disampaikan oleh gurunya disini orang tua hanya berperan sebagai pengawasan anak dalam melaksanakan pembelajarannya. Salah satu respon orang tua sebagai berikut.

"...Dengan adanya pembelajaran daring saya mengetahui kemampuan anak saya, serta mengetahu gaya belajar dari anak saya ternyata lebih cepat menangkap pembelajaran dengan auditori. Ketika anak diajarkan menyanyi saya melihatnya sangat pawai dengan intonasi dan nada dalam nyanyiannya jadi berdasarkan pengamatan saya ternyata anak saya tipikal anak belajar auditori. Serta anak saya ternyata memiliki kesulitan belajar saat melakukan hitung-hitungan. Ia sangat lama menangkap pelajaran."

Berdasarkan hasil wawancara diatas maka dalam pendampinganya orang tua mampu melihat kelebihan dan kekurangan anaknya dalam menerima pembelajaran dikelas. Dalam wawancara tersebut orang tua dengan teliti mengajari anaknya secara perlahan agar anak bisa menangkap isi dari pembelajaran yang diberikan oleh gurunya. Sehingga strategi yang digunakan oleh orang tua disini ialah teliti dan pelan pelan dalam mendapingi anak menerima pembelajara daring.

Sedangkan pendampingan di PAUD $C$ justru orang tua notabene kebanyakan berlatar belakang petani dan lokasi sekolah cendrung masuk kedalam perkampungan sehingga orang tua tidak mengerti dalam menemani anak belajar daring. Salah satu respon dari orang tua sebagai berikut.

“..saya disini sebagai petani tidak bisa baca tulis, karena dulu saya tidak bersekolah terbentur dengan biaya, namun sekarang saya sadar bahwa pendidikan sangatlah penting. Maka dari itu kami orang tua di gang ini memilih untuk gurunya mengadakan home visit dalam 1 minggu 3-4 kali menyesuaikan dengan jadwal kesanggupan gurunya. Saya disini secara pribadi sangat berterima kasih kepada buguru telah rela mengajari anak kami berepat dalam melaksankan pembelajaran.."

Strategi yang digunakan oleh orang tua disini adalah menyarankan kepada gurunya untuk berkunjung kerumah, orang tua menyepakati pembelajaran dilaksanakan dengan tetangga yang satu gang dengan maksimal berjumlah empat orang dengan menggunakan protokol kesehatan seperti masker dan menjaga jarak sedangkan dalam persesinya pembelajaran dilaksanakan satu jam penuh. Berikut foto yang sempat diabadikan oleh salah satu kepala sekolah PAUD.

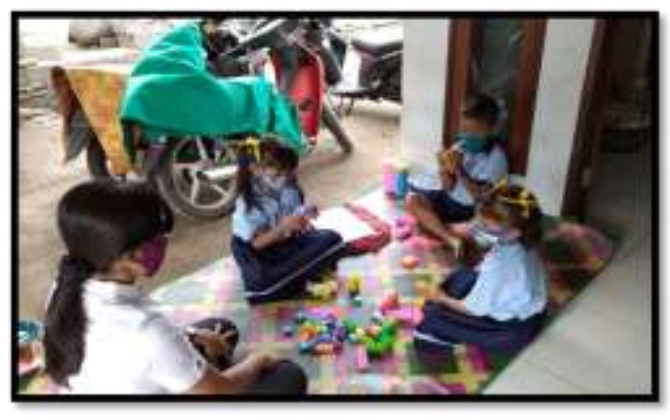


Gambar 4. Anak nampak sangat serius menerima pemebelajaran.

Melihat foto diatas bahwa orang tua menginginkan anaknya untuk mendapatkan pendidikan yang layak dan karena masih pandemi covid-19 berlangsung maka orang tua menerima upaya dari sekolah dalam mencerdaskan anak walau tidak seperti pembelajaran luring pada mumnya.

3.2 Pendampingan belajar AUD oleh Orang Tua yang tidak ada di rumah saat pembelajaran

Orang tua merupakan yang paling dekat dengan anak selama anak belajar dari rumah. Dari semua faktor eksternal, maka orangtualah yang paling berperan dalam menentukan perkembangan pembelajaran anak. Orang tua merupakan sosok pertama dan utama dalam pendidikan anak. Meskipun anak telah dititipkan ke sekolah, tetapi orang tua tetap berperan terhadap proses belajar anak. Orang tua memiliki peran yang sangat penting dalam keluarga. Orang tua merupakan guru pertama dan utama bagi anak-anaknya karena dari orang tua lah anak mendapatkan bimbingan dan kasih sayang yang pertama kalinya. Oleh karena itu, orangtua memegang peranan penting untuk mengorganisir kondisi belajar di keluarga, untuk menunjang proses belajar anak.

Berikut ini pendampingan orangtua dalam mengoptimalkan anak belajar dari rumah pada masa pandemi Covid-19 : (1) Orang tua sebagai pendidik (educator) (Saridewi \& Dewanti, 2019), artinya dalam proses pendidikan anak saat pandemi Covid-19 orang tua dapat memainkan peran dalam pembentukan karakter, fisik, motorik, sosial, emosional, moral, bahasa, kognitif, kreativitas dan Agama serta meletakkan dasar-dasar dalam kecakapan hidup. (2) Orang tua sebagai guru (Rudiarta, 2020), artinya orang tua dalam kehidupan sehari-hari dapat memainkan peran untuk melakukan kegiatan belajar, apakah itu kegiatan membaca, menulis maupun berhitung, sehingga anak-anak memiliki kesiapan untuk melakukan aktivitas seperti di sekolah. (3) Orang tua sebagai motivator, artinya orang tua dapat memotivasi anak dan mendorongnya untuk semangat belajar di rumah, sehingga membuat anak-anak menyukai kegiatan belajar. (4) Orang tua sebagai supporter, artinya orang tua harus memberikan dukungan baik moril maupun materiil yang diperlukan anak untuk melakukan kegiatan belajar di. Dukungan yang diberikan didasarkan pada prinsipprinsip pedagogis, agar bermakna bagi pertumbuhan dan perkembangan anak. (5) Orang tua sebagai fasilitator (Arini, 2019), artinya orang tua harus menyisihkan waktu, tenaga, dan kemampuannya untuk menfasilitasi segala kegiatan anak dalam proses pertumbuhan dan perkembangannya. Orang tua dapat menciptkan lingkungan yang kondusif bagi terciptanya kegiatan belajar dan bermain bagi anak di rumah. (6) Orang tua sebagai model (Suadnyana \& Yogiswari, 2019), artinya orang tua seharusnya menjadi contoh dan teladan di rumah dalam berbagai aspek kecakapan dan perilaku hidupnya, sehingga anak-anak dapat mengikuti yang baik-baik di rumah, sebelum anak-anak memasuki kehidupan di tengah-tengah masyarakat. Misalnya tutur kata, kebiasaan membaca, berdialog atau berdiskusi setiap menghadapi persoalan dengan cara yang sedemokratis mungkin dan tidak dengan sikap otoriter, respek antara sesama.

Pendidikan anak bukan hanya menjadi kewajiban guru apalagi dengan situasi pandemi Covid-19 seperti saat ini yang menyebar keseluruh dunia, pentingnya partisipasi orang tua menemani anak belajar di rumah serta menjadi teladan bagi putra-putrinya. Semua kebiasaan baik dan buruk bermula dari pembiasaan yang dilakukan orang tua terhadap anaknya. Oleh karenanya pendampingan saat pembelajaran sangatlah menentukan dalam pendidikan 
anak untuk mencapai kesuksesan (Chusna \& Utami, 2020).

Dengan diterapkannya SE Sesjen Mendikbud Nomor 15 Tahun 2020 orang tua bisa memilih pengajaran yang cocok diterapkan bagi anaknya yang tidak memberatkan bagi orang tua yang bekerja yakni orang tua ke sekolah setiap satu minggu sekali untuk mengambil tugas dan arahan yang sudah dirancang oleh guru dan orang tua juga menyetorkan hasil dari pekerjaan rumah anaknya yang diberikan waktu selama seminggu. Guru mengevaluasi perkembangan peserta didiknya melalui hasil dari pekerjaan yang dikumpulkan ke sekolah oleh orang tua siswa. dengan menerapkan cara ini tidak ada alasan bagi orang tua tidak memberikan akses atau layanan pendidikan bagi anak yang sedang belajar dari rumah. Salah satu respon dari orang tua sebagai berikut.

"saya walaupun bekerja pasti menyempatkan mendampingi anak belajar selepas pulang dari bekerja, karena dalam prinsip saya bekerja demi anak dan masadepannya, untuk itu apapun tugas yang diberikan oleh gurunya yang setiap satu minggu saya ambil kesekolah akan saya dampingi anak mengerjakannya secara bertahap"

Strategi orang tua saat mendampingi anak ialah ketika orang tua telah pulang dari bekerja dan meluangkan waktu untuk mendampingi anaknya dalam pelaksanaan pembelajaran. Orang tua harus mengetahui gaya belajar anak saat pembelajaran ada tiga gaya belajar anak pada umumnya yakni visual, auditori dan kinestetik. Masing-masing gaya belajar anak ini ada cara menanganinya seperti halnya. Salah satu respon dari orang tua sebagai berikut.

"setelah saya menemani anak saya selama dua bulan ternyata saya menyadari bahwa anak saya cenderung lebih cepat memahami pembelajaran dengan mendengar daripada membaca secara langsung. Untuk itu saya searching di internet ternyata nama gaya belajar anak saya adalah gaya auditori, jadi saya berikan anak saya metode bercerita untuk menemani anak saya belajar dari rumah.

Ada beberapa cara orang dalam menemani anak belajar dari rumah sesui dengan gaya belajar yang dimiliki oleh anak. Gaya belajar visual dengan menggunakan lebih banyak gambar, menggunakan penulisan yang variatif dan berwarna, menggunakan peta pikiran (mind mapping) penataan ruang belajar sesuai dengan kemauan anak, belajar melalui film/youtube terkait pembelajaran yang sedang dipelajari. Gaya belajar auditori yakni dengan penggunaan intonasi yang dinamis ketika memberikan informasi kepada anak, mengajarkan anak dengan tehnik bercerita, menggunakan media audiovisual dalam membantu pembelajarannya. Gaya belajar kinestetik orang tua menggunakan alat peraga, mengajarkannya secara langsung aplikasi pengetahuan sehingga anak berminat belajar dengan informasi yang mudah diingat.

\section{SIMPULAN}

Strategi yang digunakan orang tua dalam mendampingi anak usia dini belajar daring di rumah adalah strategi yang sesuai dengan SE Nomor 3 Tahun 2020 tentang Pencegahan Covid-19 di Satuan Pendidikan dan SE Sesjen Mendikbud Nomor 15 Tahun 2020 Tentang pedoman penyelenggaraan belajar dari rumah dalam masa darurat penyebaran Covid-19 orang tua atau wali peserta didik pendampingan Pembelajaran Jarak Jauh ialah secara online atau daring, ada yang semi daring, dan ada yang luring. Dua pendekatan yaitu pembelajaran jarak jauh dalam jaringan (daring) dan luar jaringan (luring) orang tua atau wali terhadap peserta didik menyesuaikan kondisi, dan ketersediaan waktu dan sarana dan prasarana pembelajaran.

Berdasarkan dari surat edaran dan penelitian diatas maka tidak ada celah atau alasan untuk tidak memberikan pemdampingan kepada anak saat belajar dari rumah dimasa pandemi Covid-19. 
Sebagai orang tua wajib mendampingi anak untuk belajar di rumah berguna untuk berkomunikasi yang bermanfaat dengan anak serta mengetahui gaya belajar anak dan daya tangkap anak sehingga orang tua bisa memberikan stimulus yang tepat untuk kemajuan pembelajaran anak.

$$
\text { Pada TK.A melaksanakan }
$$

pembelajaran dengan full daring menggunakan aplikasi platforn ZOOM Meeting, Google Classroom, WhatsApp. Strategi orang adalah menemani anak belajar, menyiapkan perangkat pembelajaran dan mengarahkan anak apabila merasa kesulitan dalam menerima pembelajaran. PAUD B melaksanakan pembelajaran semi daring dengan strategi orang tua setiap hari senin mengambil lembar kerja siswa dan mengumpulkan pekerjaan rumah siswa ke sekolah. Strategi pendampingan orang tua di PAUD $\mathrm{C}$ ialah dengan menggundang guru untuk melaksanakan pembelajaran luring dirumahnya dengan peserta siswa yang terbatas

Dengan adanya sinergisitas antara guru dan orang tua dalam pembelajaran anak maka esensi dari pembelajaran terjalin dengan baik guru tidak lagi memberikan penilaian secara kuantitatif namun lebih kepenilaian proses kemauan anak untuk belajar. Orang tua juga tidak memberikan tugas pendidikan anak hanya kepada guru disekolah namun dengan bersama-sama memberikan pendidikan yang terbaik bagi anak.

\section{DAFTAR PUSTAKA}

Ardika Yasa, I. M. (2020). Nilai-Nilai Pendidikan Dalam Budaya Tarung Presean Di Lombok Barat (Perspektif Agama Hindu). Jurnal Penelitian Agama Hindu. https://doi.org/10.25078/jpah.v4i1.13 34

Arini, N. M. (2019). Swadharma grihastha asrama on educating children toward Hindu families. International Journal of Social Sciences and Humanities. https://doi.org/10.29332/ijssh.v3n3.33
9

Deswari, N. (2015). Membangun Imajinasi dan Kreativitas Anak Melalui Literasi. In Membangun Imajinasi dan Kreativitas Anak Melalui Literasi.

Gunada, I. W. A. (2020). AJARAN AGAMA HINDU SEBAGAI INSPIRASI PENCIPTAAN KARYA SENI LUKIS TRADISIONAL BALI. Gorga : Jurnal Seni Rupa. https://doi.org/10.24114/gr.v9i1.1849 2

Hatimah, I. (2016). KETERLIBATAN KELUARGA DALAM KEGIATAN

DI SEKOLAH DALAM PERSPEKTIF KEMITRAAN. PEDAGOGIA. https://doi.org/10.17509/pedagogia.v1 $4 \mathrm{i} 2.3878$

Iftitah, S. L., \& Anawaty, M. F. (2020). PERAN ORANG TUA DALAM MENDAMPINGI ANAK DI RUMAH SELAMA PANDEMI COVID-19. JCE (Journal of Childhood Education). https://doi.org/10.30736/jce.v4i2.256

Kemdikbud, \& Kemdikbud, pengelola web. (2020). Pedoman Penyelenggaraan Belajar dari Rumah. In Jakarta, 28 Mei 2020.

Lexy J. Moleong, D. M. A. (2019). Metodologi Penelitian Kualitatif (Edisi Revisi). PT. Remaja Rosda Karya. https://doi.org/10.1016/j.carbpol.2013 .02 .055

Mutiah. (2016). Meningkatkan hasil belajar pendidikan agama islam dengan menerapkan model pembelajaran kolaborasi pada siswa kelas VI SDN Tlogohaji Sumberrejo Bojonegoro. Jurnal Karya Pendidikan.

Okmawati, M. (2020). The Use of Google Classroom during Pandemic. Journal of English Language Teaching. https://doi.org/10.24036/jelt.v9i2.109 293

Pendidikan, K. K. (2020). Mendikbud 
Terbitkan SE tentang Pelaksanaan

Pendidikan dalam Masa Darurat

Covid-19. Kemdikbud.

Puji Asmaul Chusna, \& Ana Dwi Muji

Utami. (2020). DAMPAK PANDEMI

COVID-19 TERHADAP PERAN

ORANG TUA DAN GURU DALAM

MENINGKATKAN KUALITAS

PEMBELAJARAN DARING ANAK

USIA SEKOLAH DASAR.

PREMIERE : Journal of Islamic

Elementary Education.

https://doi.org/10.51675/jp.v2i1.84

Purwanto, A., \& Adriyani, Y. (2020).

Studi Eksplorasi Dampak Work From

Home ( WFH ) Terhadap Kinerja

Guru Selama Pandemi Covid-19. In

EduPsyCouns: Journal of Education,

Psychology and Counseling.

Rudiarta, I. W. (2020). Implikasi Latihan

Yoga Asana Bagi Pembentukan

Karakter Siswa Di Ashram Gandhi

Puri Sevagram Klungkung. Jurnal

Penelitian Agama Hindu.

https://doi.org/10.25078/jpah.v4i1.13

14

Rulandari, N. (2020). The Impact of the

Covid-19 Pandemic on the World of

Education in Indonesia. Agribusiness.

Saridewi, D. P., \& Dewanti, P. (2019).

Application of Learning Materials

Design for Hindu Religious Subject

in Special Education.

https://doi.org/10.4108/eai.21-11-

2018.2282023

Suadnyana, I. bagus P. eka, \& Yogiswari,

K. S. (2019). UPANISAD

PERSPEKTIF PENDIDIKAN

MODERN. Jurnal PASUPATI.

https://doi.org/10.37428/pspt.v6i2.13

6

UNESCO. (2020). Covid-19 Education:

From disruption to recovery. Unesco.

World Health Organization. (2021). WHO

Coronavirus Disease 2019 (COVID-

19) Dashboard. WHO.Int. 